\title{
Oxidation of SiC Fiber-Reinforced SiC Matrix Composites With a BN Interphase
}

\author{
Elizabeth J. Opila, Meredith K. Boyd* \\ NASA Glenn Research Center \\ 21000 Brookpark Rd. \\ Cleveland, $\mathrm{OH} 44135$ \\ opila@nasa.gov \\ *University of Rochester \\ Department of Chemical Engineering \\ Rochester, NY
}

SiC-fiber reinforced $\mathrm{SiC}$ matrix composites with a BN interphase were oxidized in reduced oxygen partial pressures of oxygen to simulate the environment for hypersonic vehicle leading edge applications. The constituent fibers as well as composite coupons were oxidized in oxygen partial pressures ranging from $1000 \mathrm{ppm} \mathrm{O}_{2}$ to $5 \% \mathrm{O}_{2}$ balance argon. Exposure temperatures ranged from $816^{\circ} \mathrm{C}$ to $1353^{\circ} \mathrm{C}\left(1500^{\circ} \mathrm{F}\right.$ to $\left.2450^{\circ} \mathrm{F}\right)$. The oxidation kinetics of the coated fibers were monitored by thermogravimetric analysis (TGA). An initial rapid transient weight gain was observed followed by parabolic kinetics. Possible mechanisms for the transient oxidation are discussed. One edge of the composite coupon seal coat was ground off to simulate damage to the composite which allowed oxygen ingress to the interior of the composite. Oxidation kinetics of the coupons were characterized by scanning electron microscopy since the weight changes were minimal. It was found that sealing of the coupon edge by silica formation occurred. Differences in the amount and morphology of the sealing silica as a function of time, temperature and oxygen partial pressure are discussed. Implications for use of these materials for hypersonic vehicle leading edge materials are summarized. 


\title{
Oxidation of SiC fiber-reinforced $\mathrm{SiC}$ matrix composites with a BN interphase
}

\author{
Elizabeth Opila \\ NASA Glenn Research Center \\ Cleveland, $\mathrm{OH}$ \\ Meredith K. Boyd \\ University of Rochester \\ Rochester, NY
}

$8^{\text {th }}$ Spring Meeting of the International Society of Electrochemistry

Columbus, $\mathrm{OH}$

$$
\text { May 5, } 2010
$$




\section{Motivation}

Technical challenge for hypersonic vehicles

Develop lightweight, durable, reusable, $3000^{\circ} \mathrm{F}\left(1650^{\circ} \mathrm{C}\right)$

structurally-integrated Thermal Protection Systems (TPS) to

carry both thermal and mechanical loads using ceramic matrix composite materials

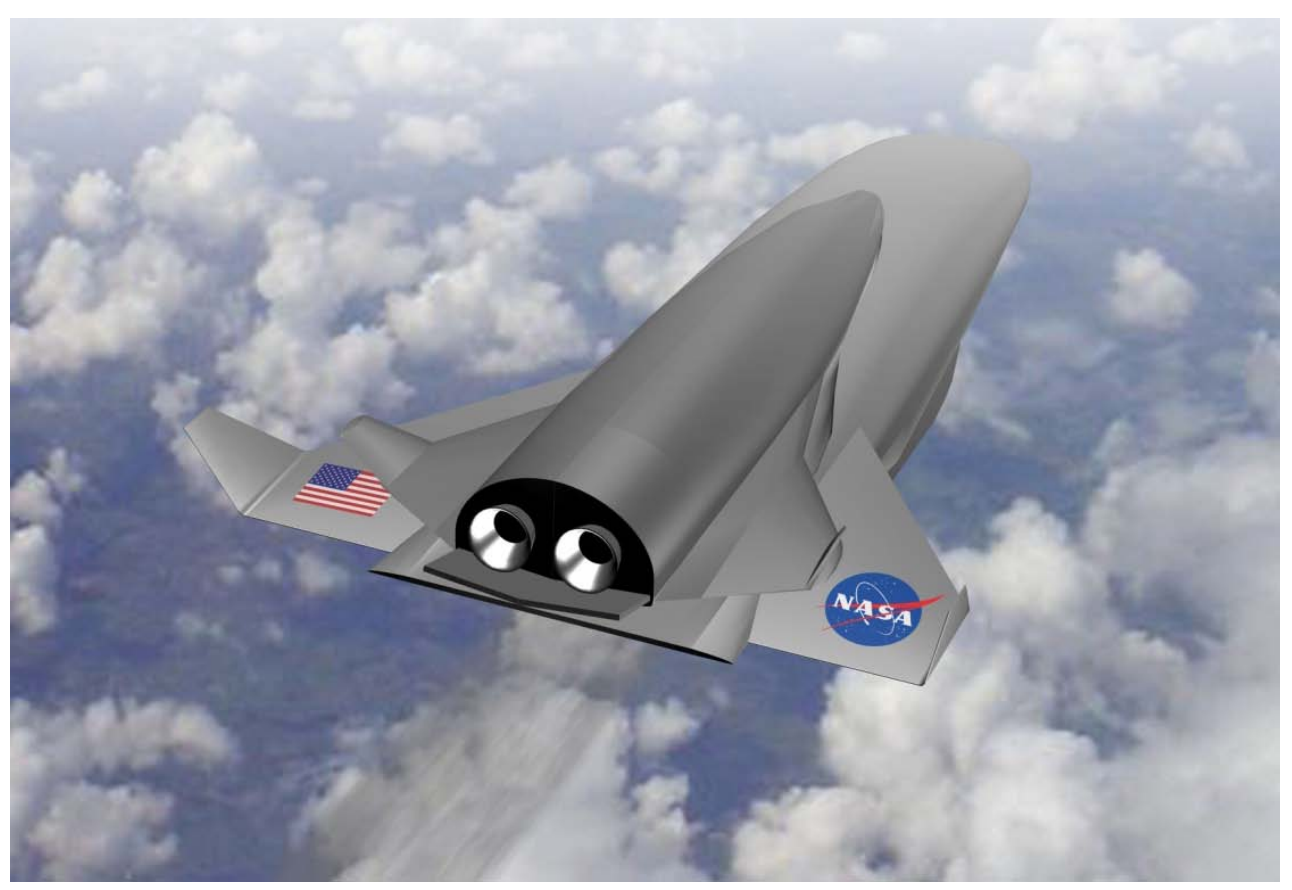




\section{Objectives}

- Characterize the oxidation resistance of BN-coated $\mathrm{SiC}$ fiber-reinforced $\mathrm{SiC}$ composites at temperatures and oxygen partial pressures relevant for hypersonic environments

- Develop understanding of oxidation degradation kinetics and mechanisms

- Provide data to Materials Research and Design, Inc. for incorporation in FEM for SiC/SiC degradation 


\section{Oxidation reactions}

Oxide formation

$$
\begin{aligned}
& \mathrm{SiC}+3 / 2 \mathrm{O}_{2}(\mathrm{~g})=\mathrm{SiO}_{2}+\mathrm{CO}(\mathrm{g}) \\
& 2 \mathrm{BN}+3 / 2 \mathrm{O}_{2}(\mathrm{~g})=\mathrm{B}_{2} \mathrm{O}_{3}+\mathrm{N}_{2}(\mathrm{~g}) \\
& \mathrm{SiO}_{2}+\mathrm{B}_{2} \mathrm{O}_{3}=\text { borosilicate glass }
\end{aligned}
$$

Oxide volatilization

$$
\begin{gathered}
\mathrm{B}_{2} \mathrm{O}_{3}=\mathrm{B}_{2} \mathrm{O}_{3}(\mathrm{~g}) \\
\mathrm{B}_{2} \mathrm{O}_{3}+1 / 2 \mathrm{O}_{2}(\mathrm{~g})=2 \mathrm{BO}_{2}(\mathrm{~g}) \\
\mathrm{B}_{2} \mathrm{O}_{3}+\mathrm{H}_{2} \mathrm{O}(\mathrm{g})=2 \mathrm{HBO}_{2}(\mathrm{~g})
\end{gathered}
$$




\section{Materials}

- Sylramic iBN fibers

- Stoichiometric polycrystalline $\beta$-SiC

- 3 wt $\% \mathrm{TiB}_{2}, 1.3$ wt \% B $\mathrm{B}_{4} \mathrm{C}, 0.7 \mathrm{wt} \% \mathrm{BN}^{\star}$

- 10 $\mu \mathrm{m}$ diameter

- Heat treated in $\mathrm{N}_{2}$ to form in situ $\mathrm{BN}$ surface layer (iBN), <100 nm

- 800 fibers/tow

- $\mathrm{SiC} / \mathrm{BN} / \mathrm{SiC}$ composites

- Sylramic iBN fibers

- CVI Si-doped BN-coated fabric

- CVI SiC matrix
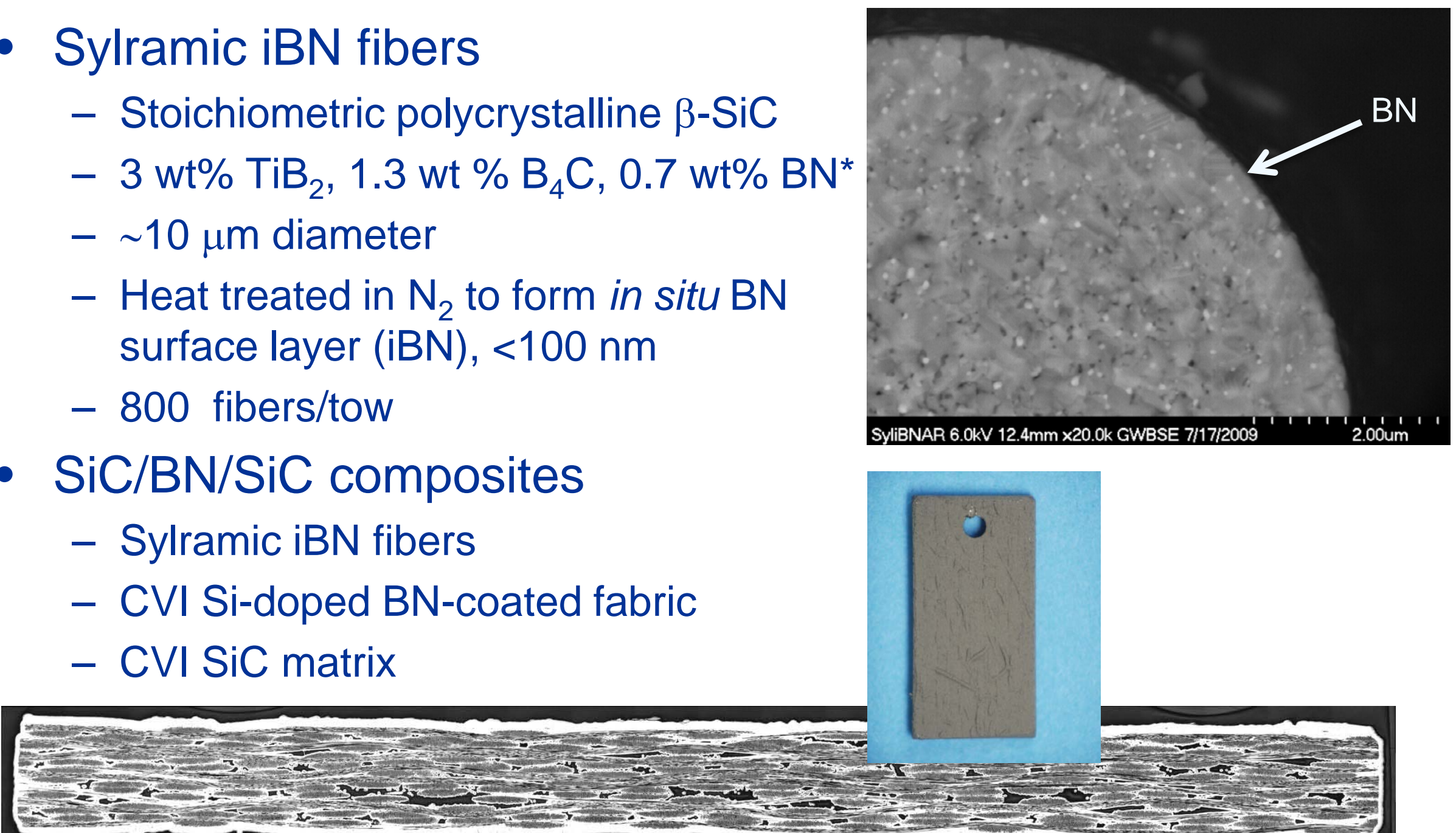


\section{Experimental Procedure}

- ThermoGravimetric Analysis (TGA)

- $5 \% \mathrm{O}_{2} / \mathrm{Ar}$ or $1000 \mathrm{ppm} \mathrm{O} / \mathrm{Ar}, 100 \mathrm{sccm}(0.4 \mathrm{~cm} / \mathrm{sec})$

- 816, $1149,1343^{\circ} \mathrm{C}\left(1500,2100,2450^{\circ} \mathrm{F}\right)$

- 100h maximum time, shorter times to investigate kinetics

- Fibers twisted into "lanyards" that can be suspended directly from sapphire hangers to prevent reaction with containers

- $8 \mathrm{~cm}$ length, 6 "lanyards" 800 fibers each, $235 \mathrm{~cm}^{2}, 0.17 \mathrm{~g}$

- $\mathrm{SiC} / \mathrm{BN} / \mathrm{SiC}$ coupons with seal coat on bottom edge ground off

$-2.5 \mathrm{~cm} \times 1.3 \mathrm{~cm} \times 0.3 \mathrm{~cm}, \sim 9 \mathrm{~cm}^{2}, 2 \mathrm{~g}$

- SEM, EDS to characterize oxidation products
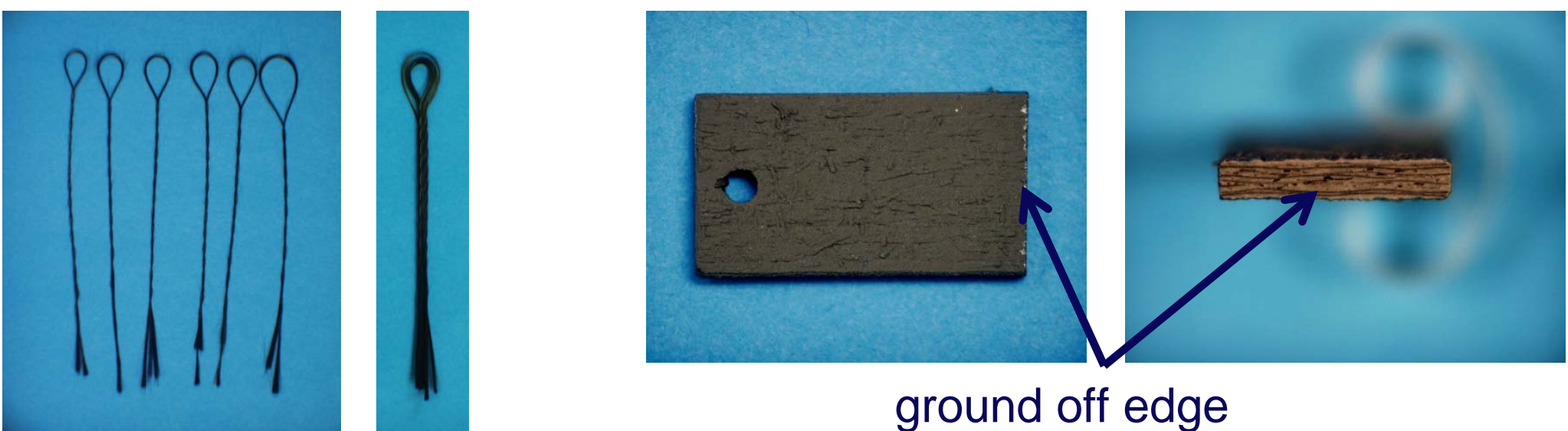

ground off edge 


\section{Oxidation weight change for Sylramic iBN fibers}

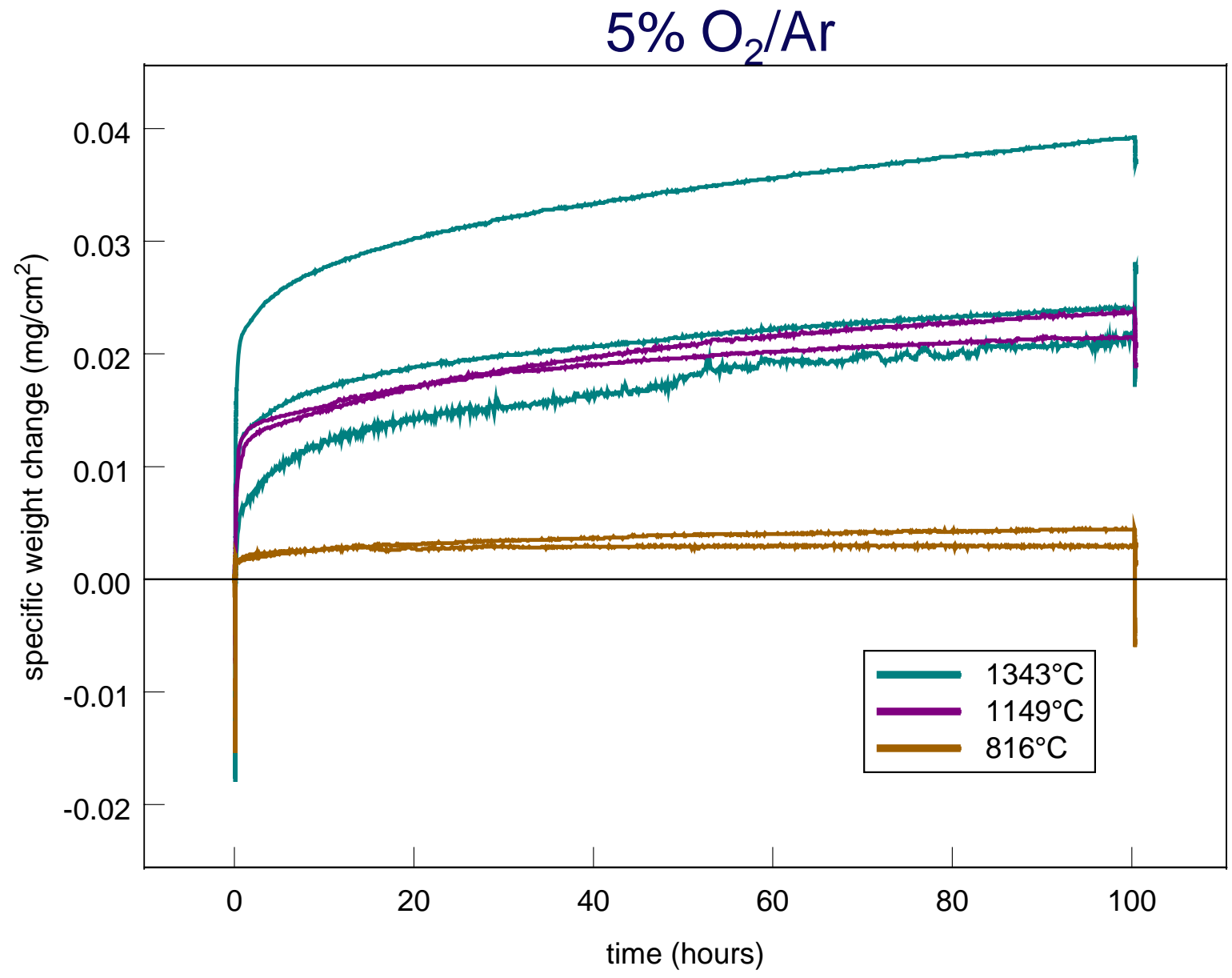

- Rapid transient weight gain followed by slow oxidation rate

- Variation in weight gain during transient phase at $1343^{\circ} \mathrm{C}$ 


\section{"Parabolic" oxidation kinetics observed after transient}

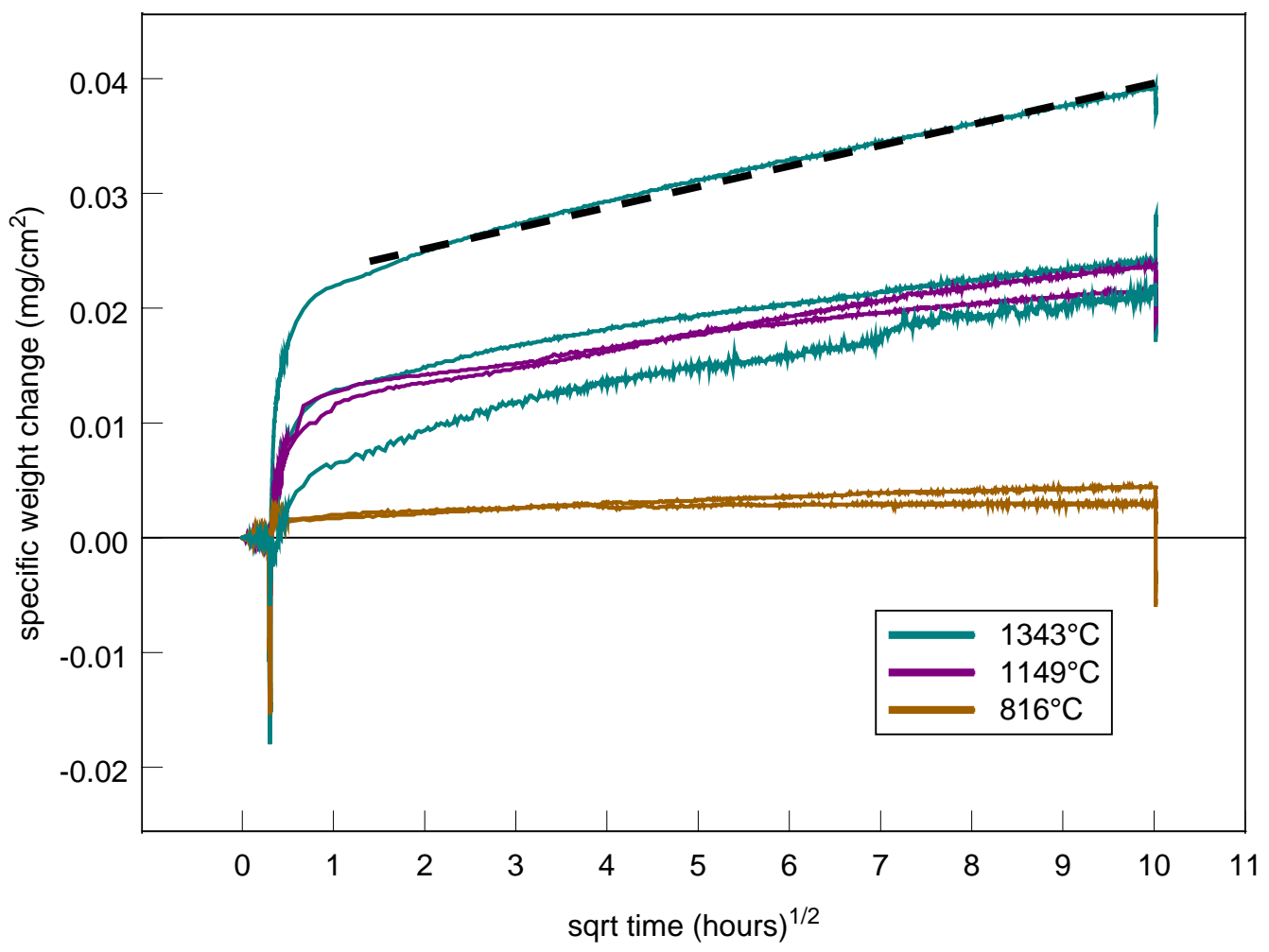

- Low rates and balance drift result in large uncertainty in measured slopes, rate constants

- Apparent parabolic rates are slower than those predicted for oxidation of pure SiC 


\section{Reduced fiber oxidation rates at low $\mathrm{P}\left(\mathrm{O}_{2}\right)$ $1000 \mathrm{ppm}_{2}$}

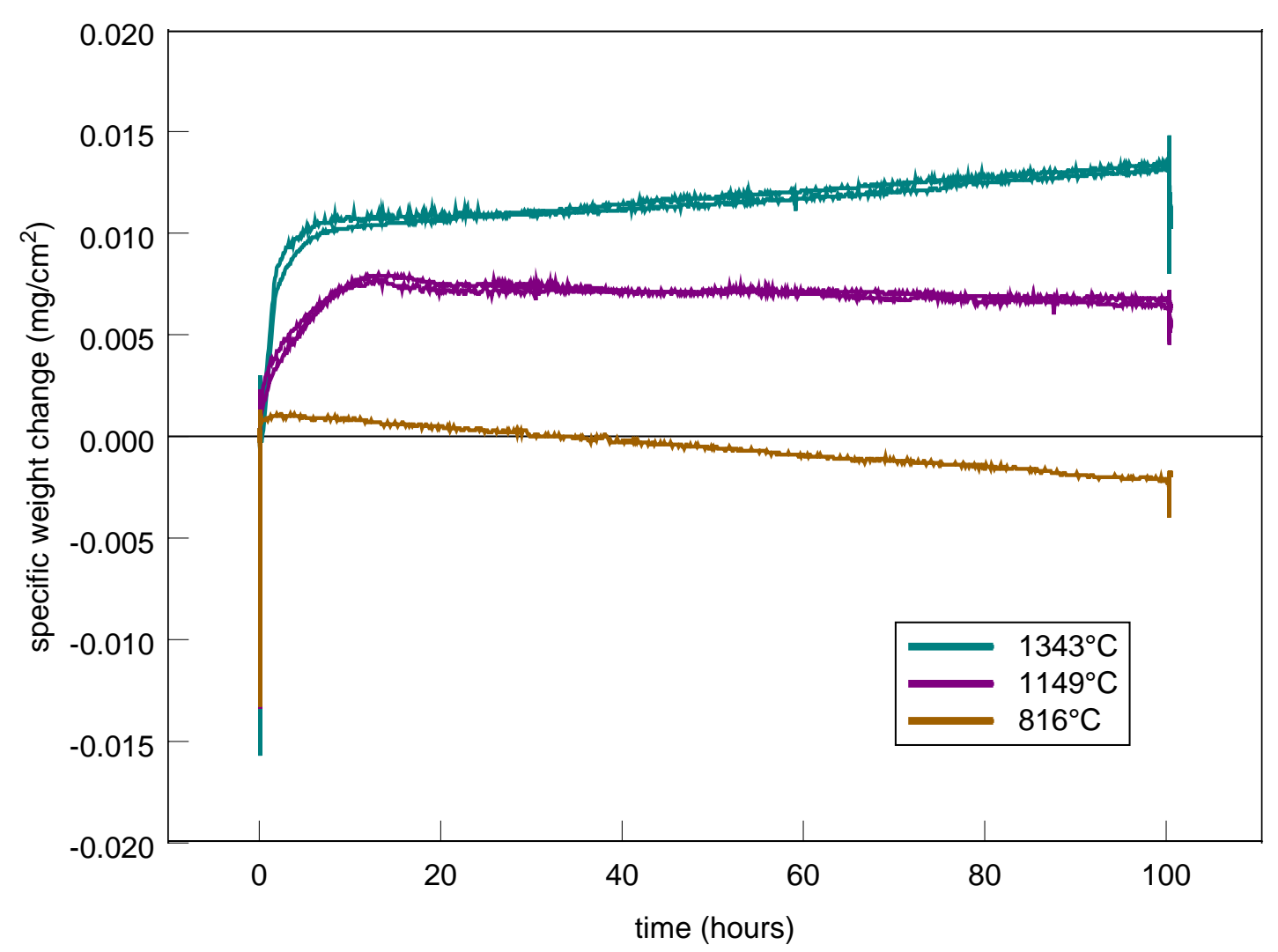

- Rapid transient oxidation rates also observed at low oxygen partial pressures

- Weight loss observed at $816^{\circ} \mathrm{C}$ 


\section{Microstructure of oxidized fibers}

plan view and fracture sections, $5 \% \mathrm{O}_{2} / \mathrm{Ar}, 100 \mathrm{hr}$

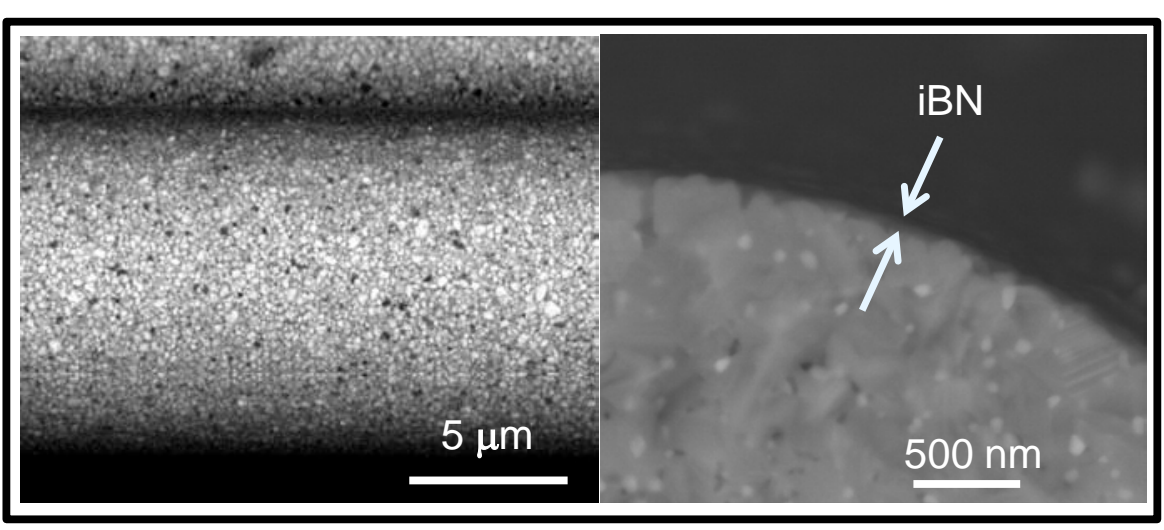

as-received

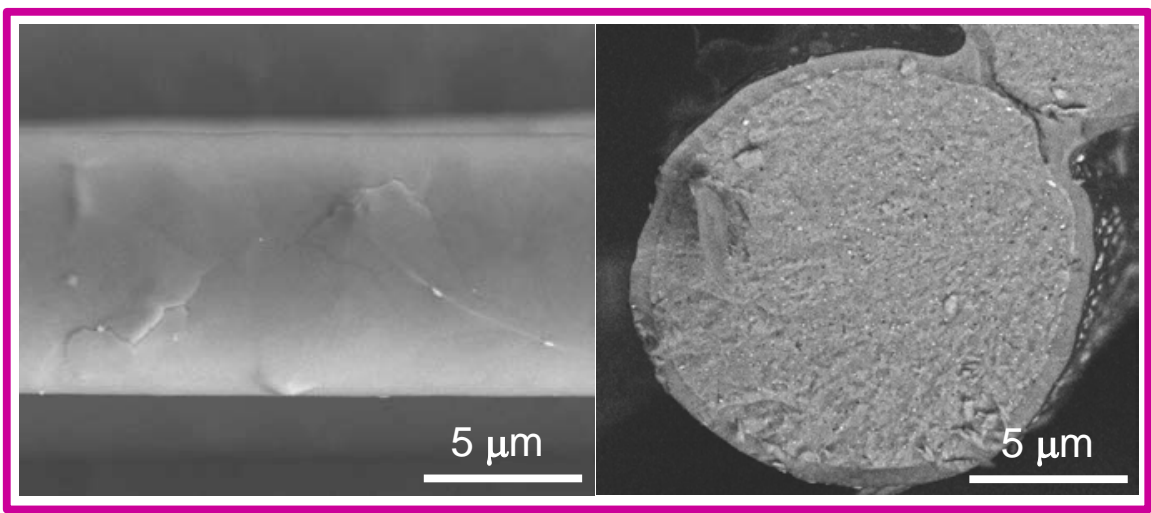

$1149^{\circ} \mathrm{C}$

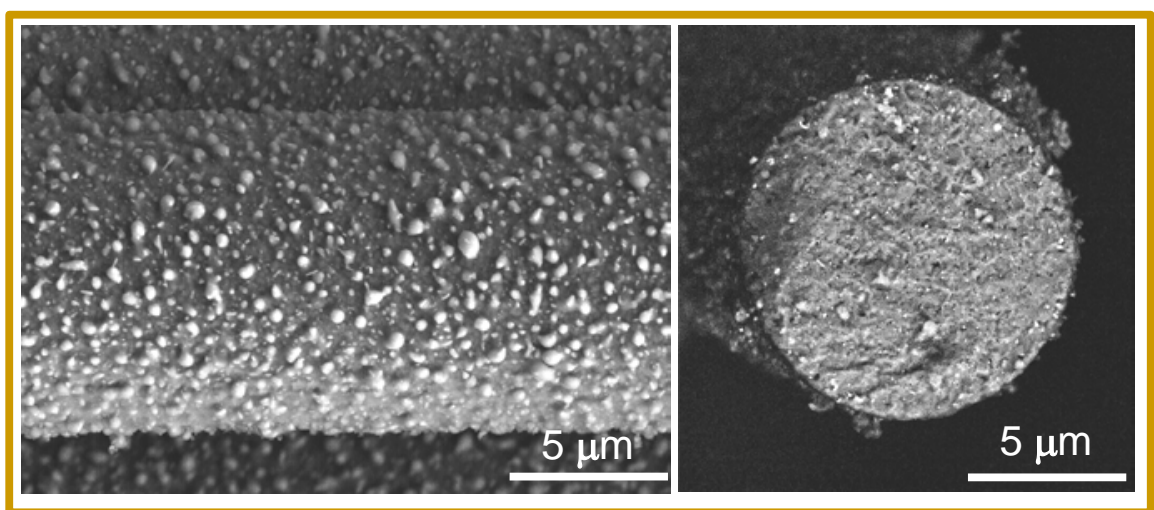

$816^{\circ} \mathrm{C}$

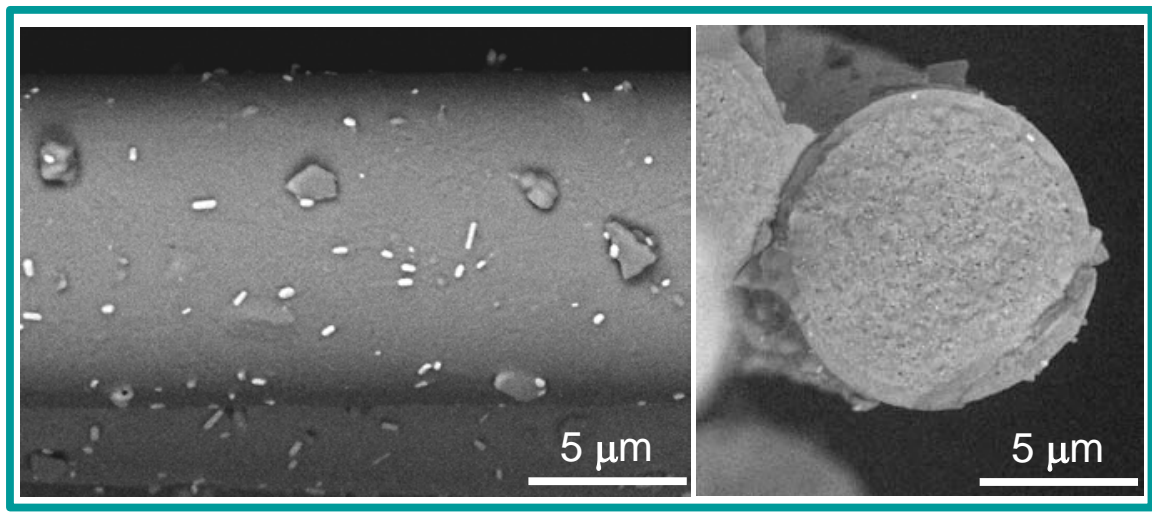

$1343^{\circ} \mathrm{C}$

Thickness of oxide scales consistent with weight change 


\section{Microstructure of oxidized fibers}

plan view and fracture sections, $5 \% \mathrm{O}_{2} / \mathrm{Ar}, 0.5 \mathrm{hr}$

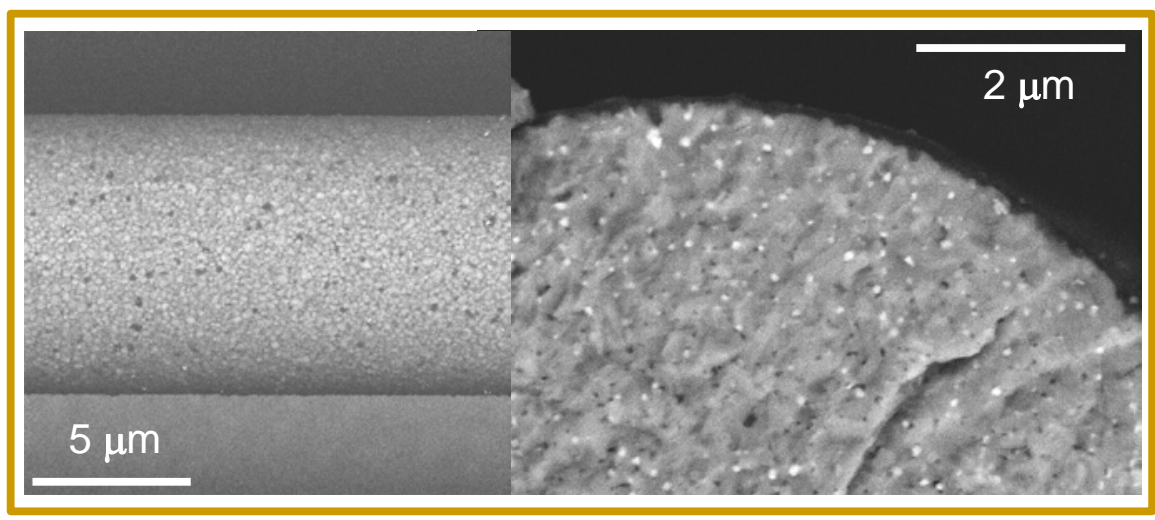

No obvious oxidation after $0.5 \mathrm{hr}$ exposure at $816^{\circ} \mathrm{C}$

$816^{\circ} \mathrm{C}$

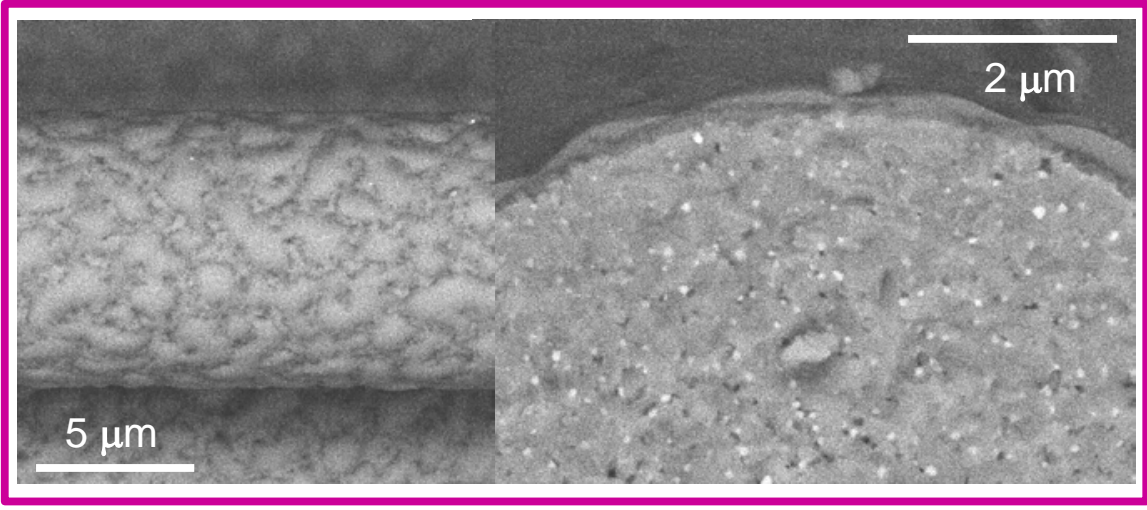

$1149^{\circ} \mathrm{C}$

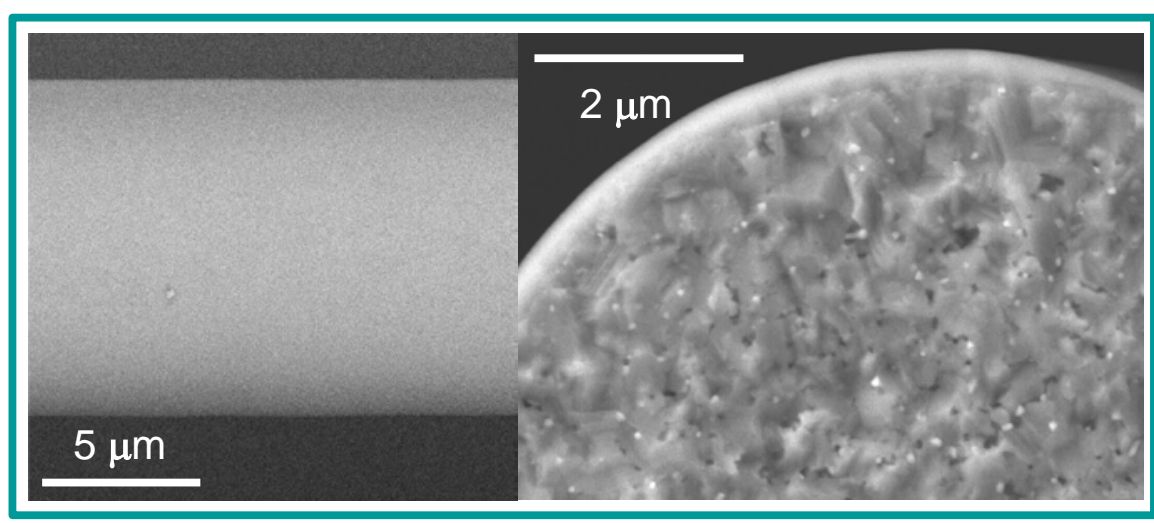

$1343^{\circ} \mathrm{C}$

Thick oxide scales observed after oxidation at short times consistent with rapid transient weight change 


\section{Microstructure of oxidized fibers}

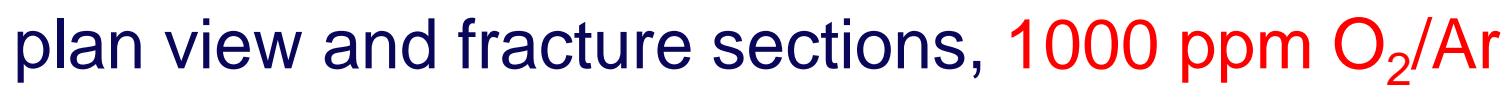

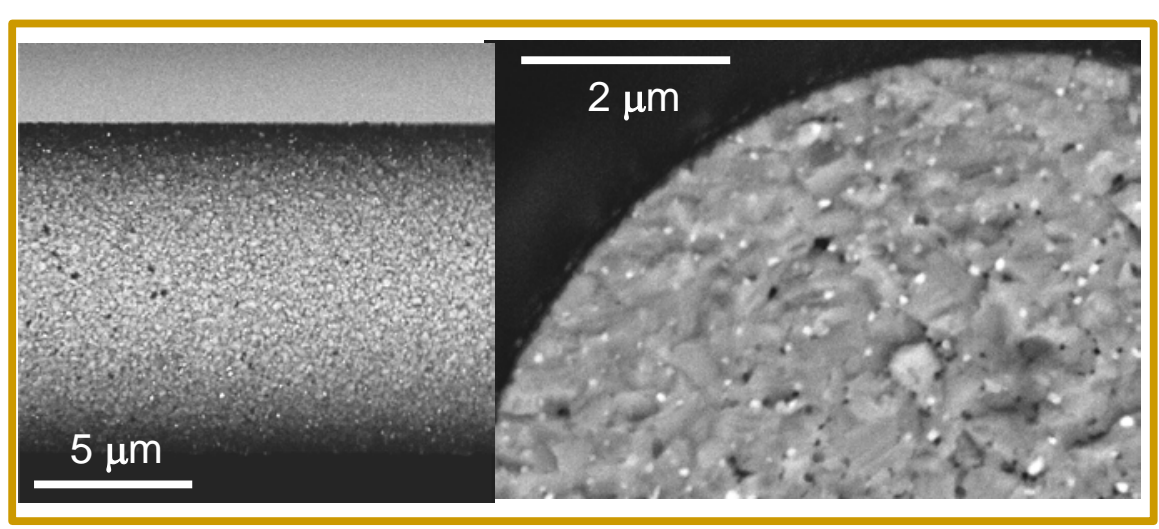

$816^{\circ} \mathrm{C}, 100 \mathrm{hr}$

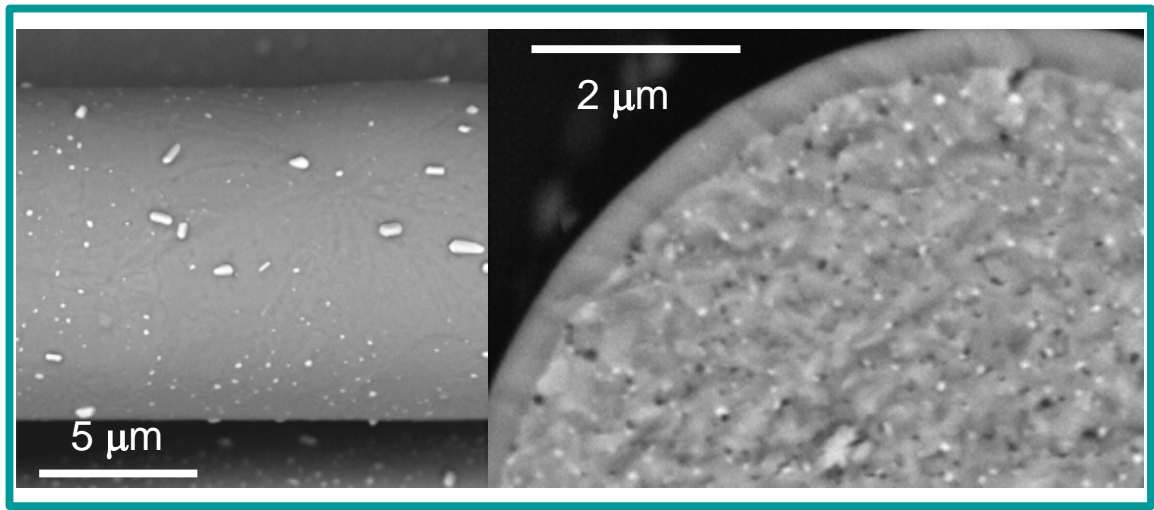

$1343^{\circ} \mathrm{C}, 100 \mathrm{hr}$

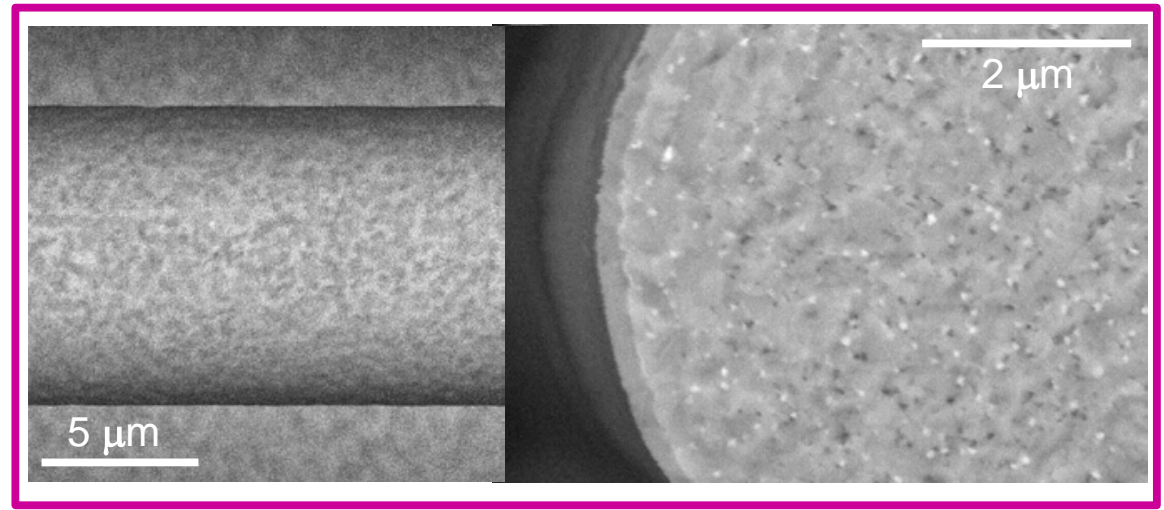

$1149^{\circ} \mathrm{C}, 100 \mathrm{hr}$

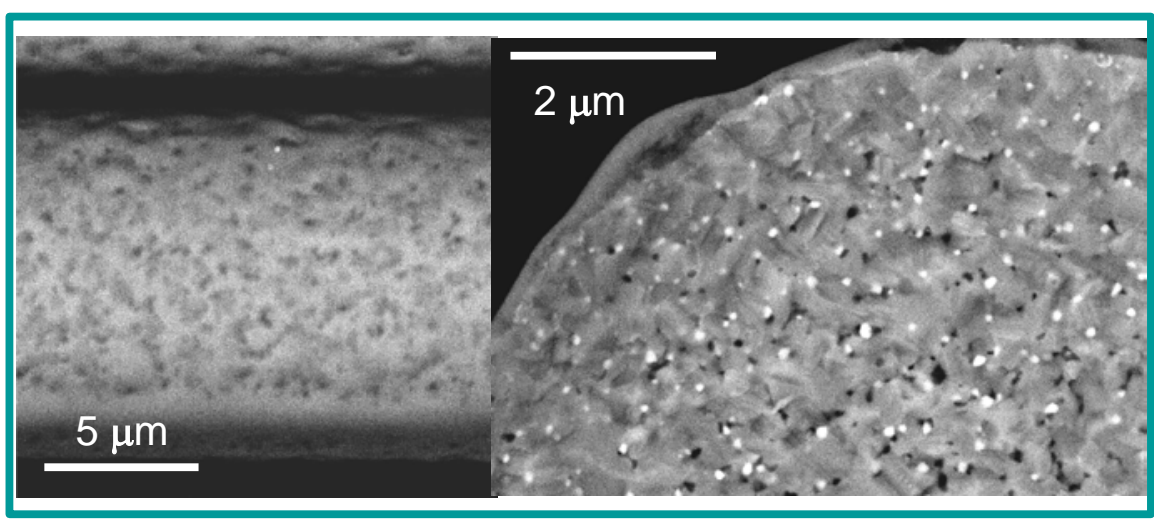

$1343^{\circ} \mathrm{C}, 1 \mathrm{hr}$

Oxide formation observed at 1149 and $1343^{\circ} \mathrm{C}$ even at this low oxygen partial pressure 


\section{Chemical composition of oxide scales: $\mathrm{SiO}_{2}$}
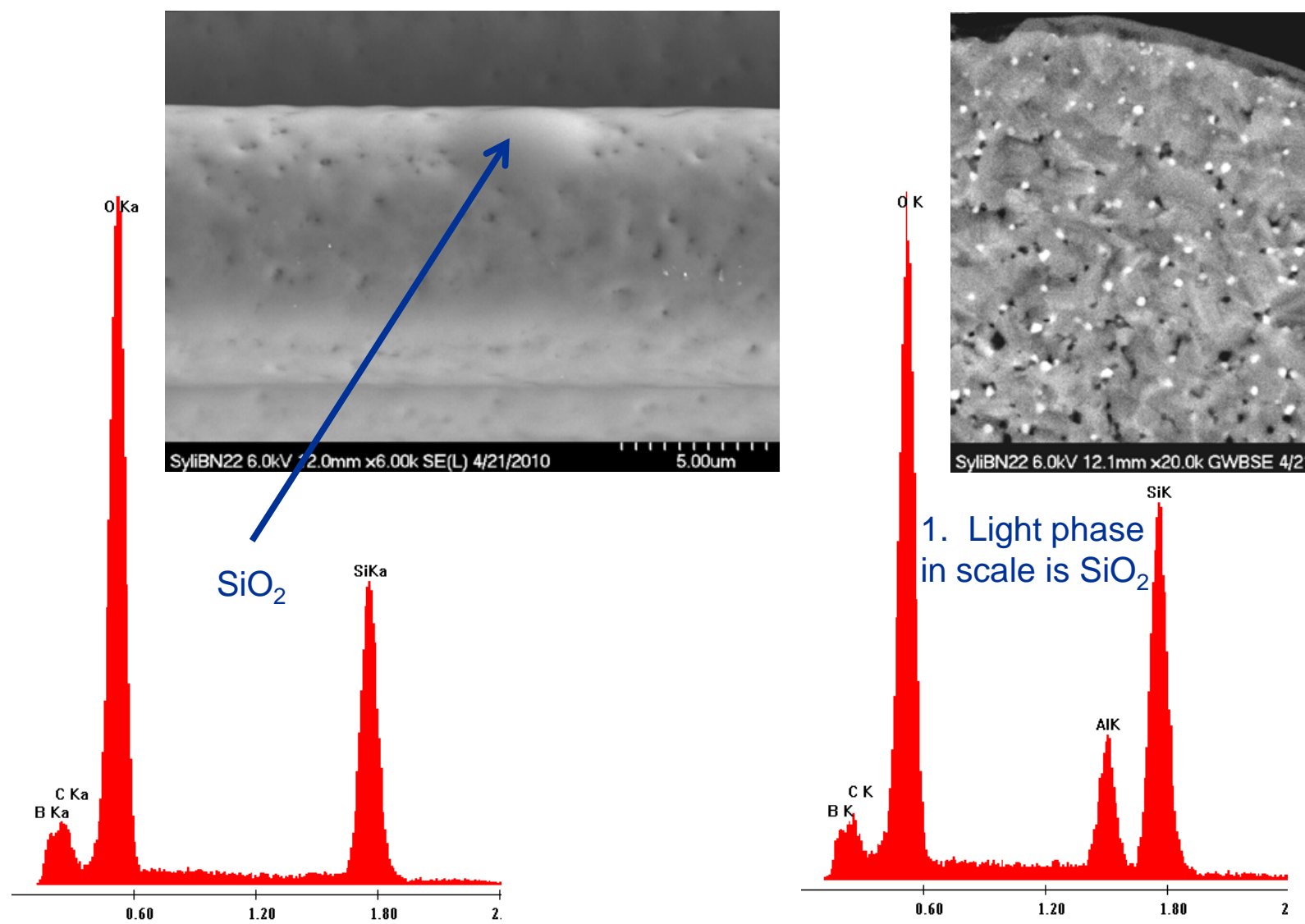

2. Dark phase in scale is $\mathrm{BN}$ surrounded by $\mathrm{SiO}_{2}$ ?

Insignificant boron detected in $\mathrm{SiO}_{2}$ by EDS even after $1 \mathrm{hr}$ exposure, $1343^{\circ} \mathrm{C}, 1000 \mathrm{ppm} \mathrm{O}_{2} /$ Ar when rapid transient is midway. Boron doping of silica rather than borosilicate glass formation is hypothesized. 


\section{Possible mechanism for Sylramic iBN fiber oxidation}

- Thin film of boria, borosilicate or B-doped silica forms on fiber

- Rapid transport of oxygen through B-affected silica scale leads to rapid initial transient in oxidation kinetics

- BN layer consumed

- B-species diffuses out of scale and is volatilized

- Kinetics slow to those found for oxidation of pure SiC 


\section{Sylramic iBN Fiber Oxidation Summary}

- Oxidation of iBN fibers occurs for all conditions studied except for $816^{\circ} \mathrm{C}$ in 1000 ppm $\mathrm{O}_{2}$

- Rapid transient oxidation of BN results in rapid growth of silica layer

- Borosilicate glass is not observed

- B-doping of silica scale proposed to explain initial rapid oxidation rate of fibers

- Rapid initial oxidation rate may be beneficial to composite performance in hypersonics environment

- Rapid sealing of exposed BN interphase to limit degradation 


\section{SiC/BN/SiC composite oxidation}




\section{Oxidation weight change of $\mathrm{SiC} / \mathrm{BN} / \mathrm{SiC}$ coupons}

Weight change for SiC/BN/SiC coupons (bottom edge SiC seal coat ground off) in $5 \% \mathrm{O}_{2} / \mathrm{Ar}$ environment is minimal at all temperatures for 24 and $100 \mathrm{hr}$ exposures

- $\Delta \mathrm{m}<0.4 \mathrm{mg}$

- $\Delta \mathrm{m}$ on the order of expected drift in TGA signal

- Rely on SEM/EDS of $\mathrm{SiO}_{2}$ formed/BN consumed in coupons exposed for $24 \mathrm{~h}$ and $100 \mathrm{~h}$ to characterize oxidation kinetics

- Section coupons and look for distance of oxygen ingress, loss of BN from open edge

section line

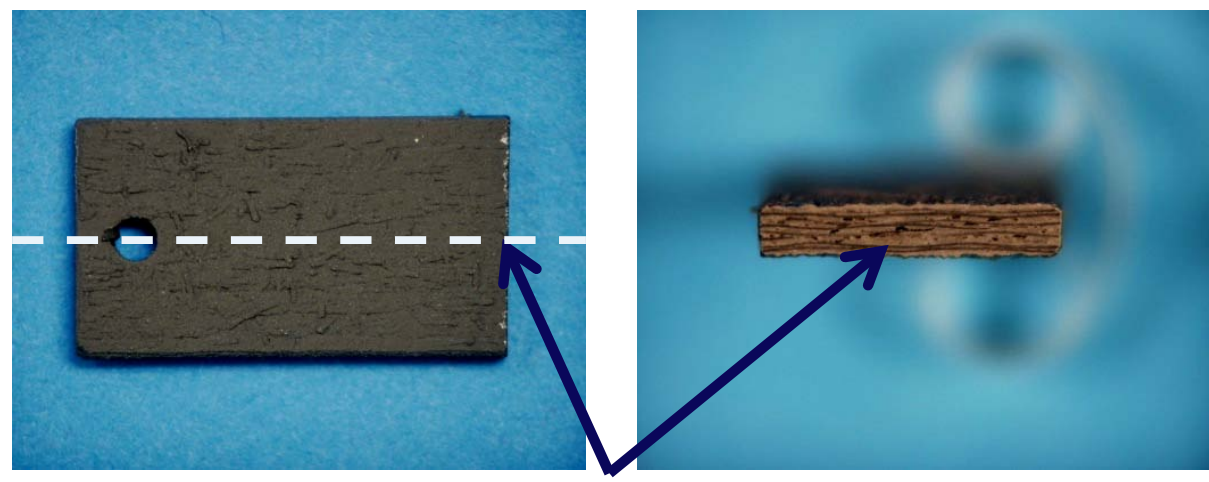

ground off edge 


\section{Oxidation weight change of $\mathrm{SiC} / \mathrm{BN} / \mathrm{SiC}$ coupons}

Weight loss observed in $1000 \mathrm{ppm} \mathrm{O}_{2} / A r$ environment at all temperatures studied. BN loss without $\mathrm{SiO}_{2}$ formation? Need SEM/EDS characterization.

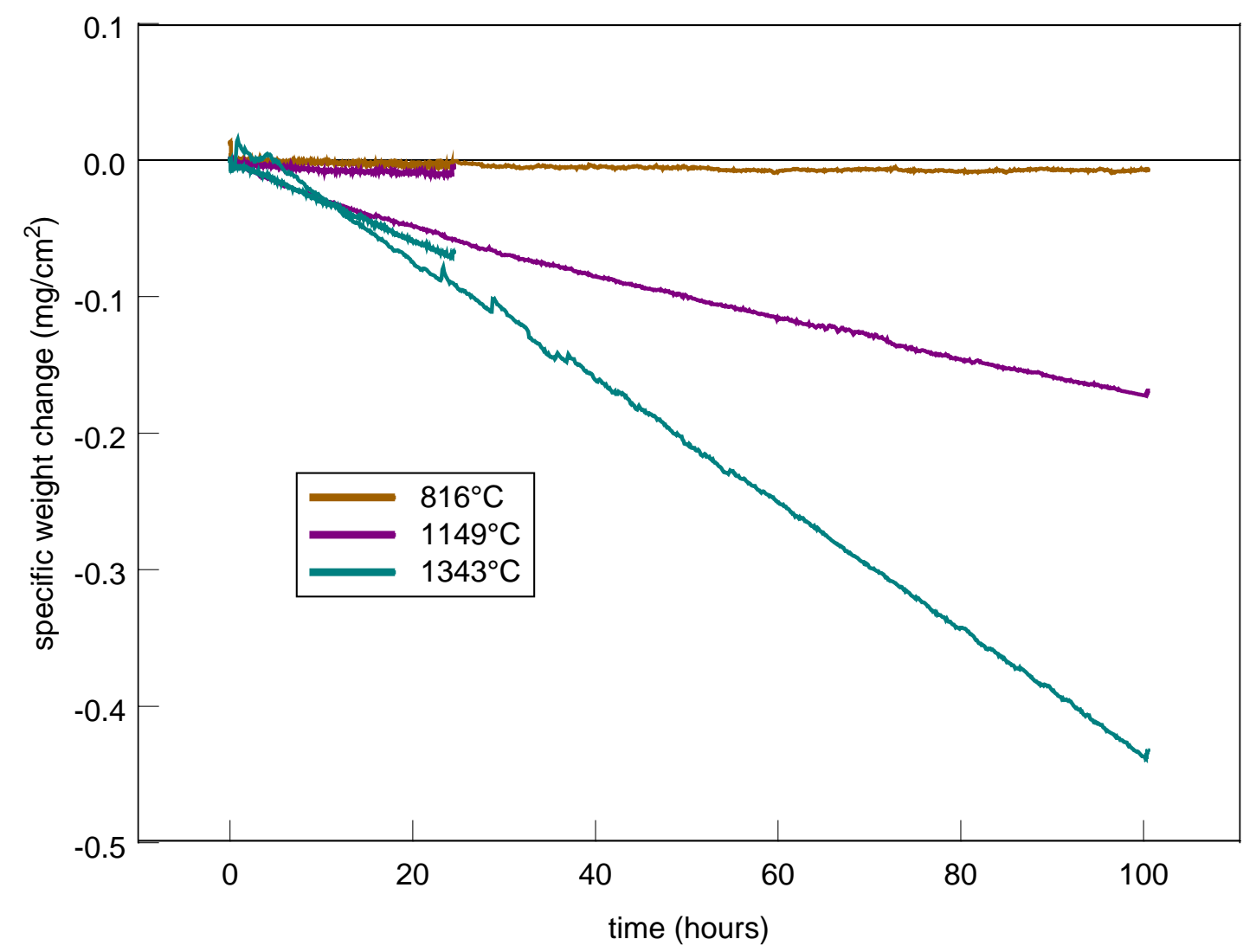




\section{Microscopy of SiC/BN/SiC composites}

- All samples polished with non-aqueous procedures to preserve any $\mathrm{B}_{2} \mathrm{O}_{3}$ in scale $-\mathrm{B}_{2} \mathrm{O}_{3}$ sensitive to moisture

- $\mathrm{BN}$ interphase polishes more easily than SiC

- Interphase recessed relative to surrounding $\mathrm{SiC}$ and $\mathrm{SiO}_{2}$

- BN EDS signal obtained where shadowing of surrounding fibers/matrix is minimal

- Interaction volume of $6 \mathrm{kV}$ electron beam in SiC/BN/SiC prevents EDS sampling of BN interphase alone

- BN: $\sim 1 \mu \mathrm{m}$ interaction volume, interphase width is $\sim 0.3 \mu \mathrm{m}$

- $\mathrm{SiC} \& \mathrm{SiO}_{2}: \sim 0.5 \mu \mathrm{m}$ interaction volume

- In cases where $\mathrm{SiO}_{2}$ formation is minimal and BN is lost to oxidation, difficult to distinguish between $\mathrm{BN}$ and epoxy: same phase contrast, same appearance. Must use point EDS in selective areas where shadowing is not a problem. 


\section{Microstructure of Oxidized Coupons}

$1343^{\circ} \mathrm{C}, 5 \% \mathrm{O}_{2} / \mathrm{Ar}, 100 \mathrm{~h}$
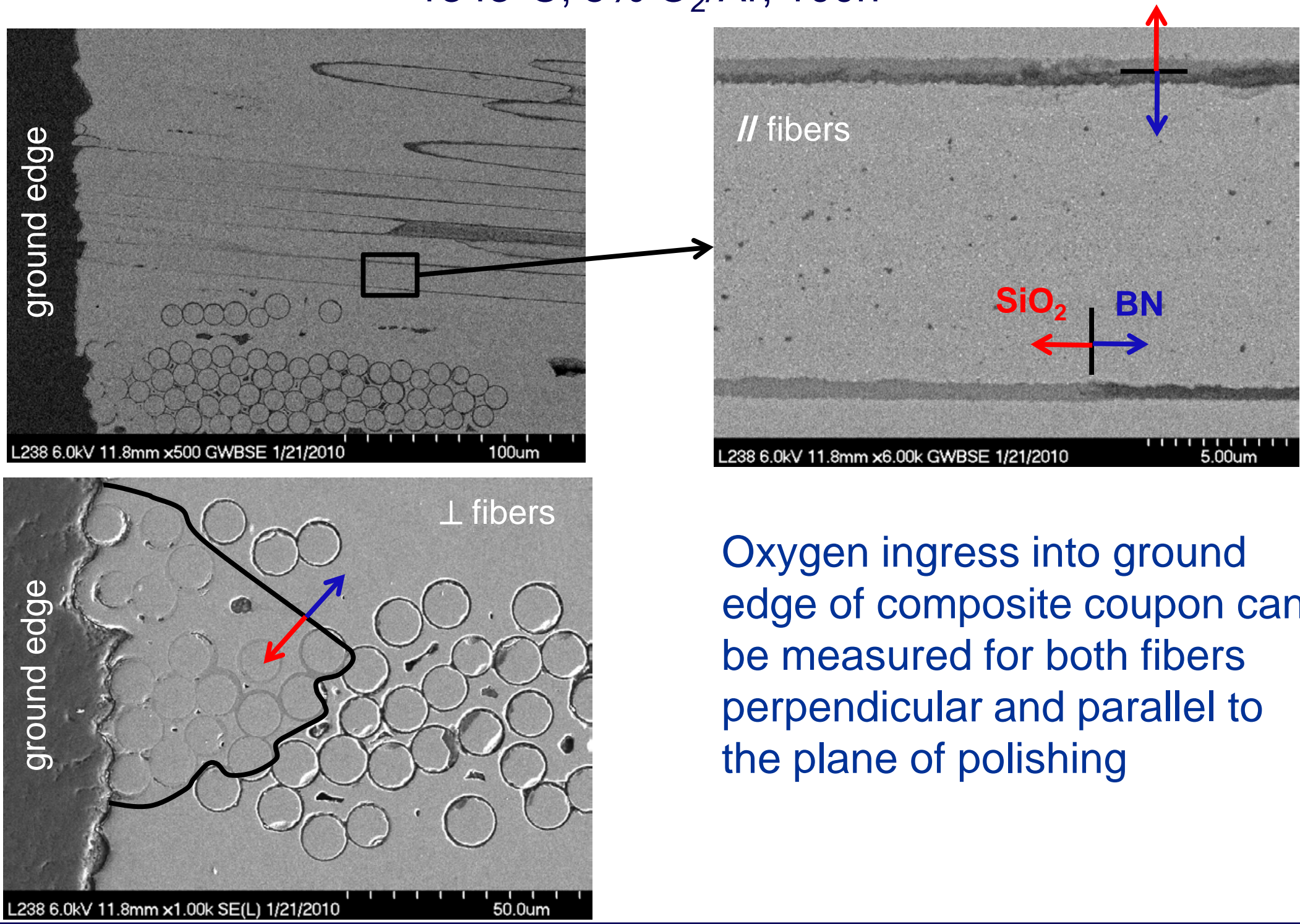

Oxygen ingress into ground edge of composite coupon can be measured for both fibers perpendicular and parallel to the plane of polishing 


\section{Microstructure/Composition of Oxidized Coupons}

$1343^{\circ} \mathrm{C}, 5 \% \mathrm{O}_{2} / \mathrm{Ar}, 100 \mathrm{~h}$
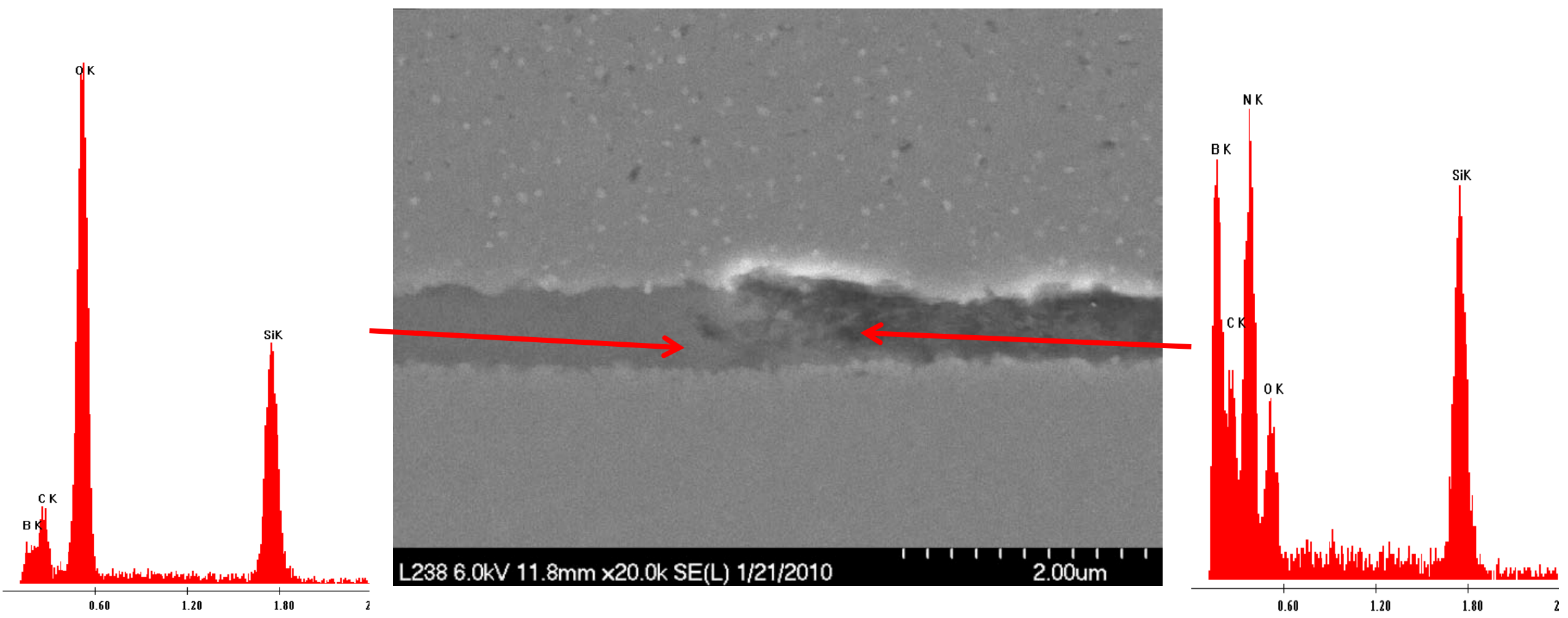

Interface between $\mathrm{SiO}_{2}$ and $\mathrm{BN}$ observed. Nitrogen is present with boron. No B-rich borosilicate glass. 


\section{Microstructure of Oxidized Coupons}
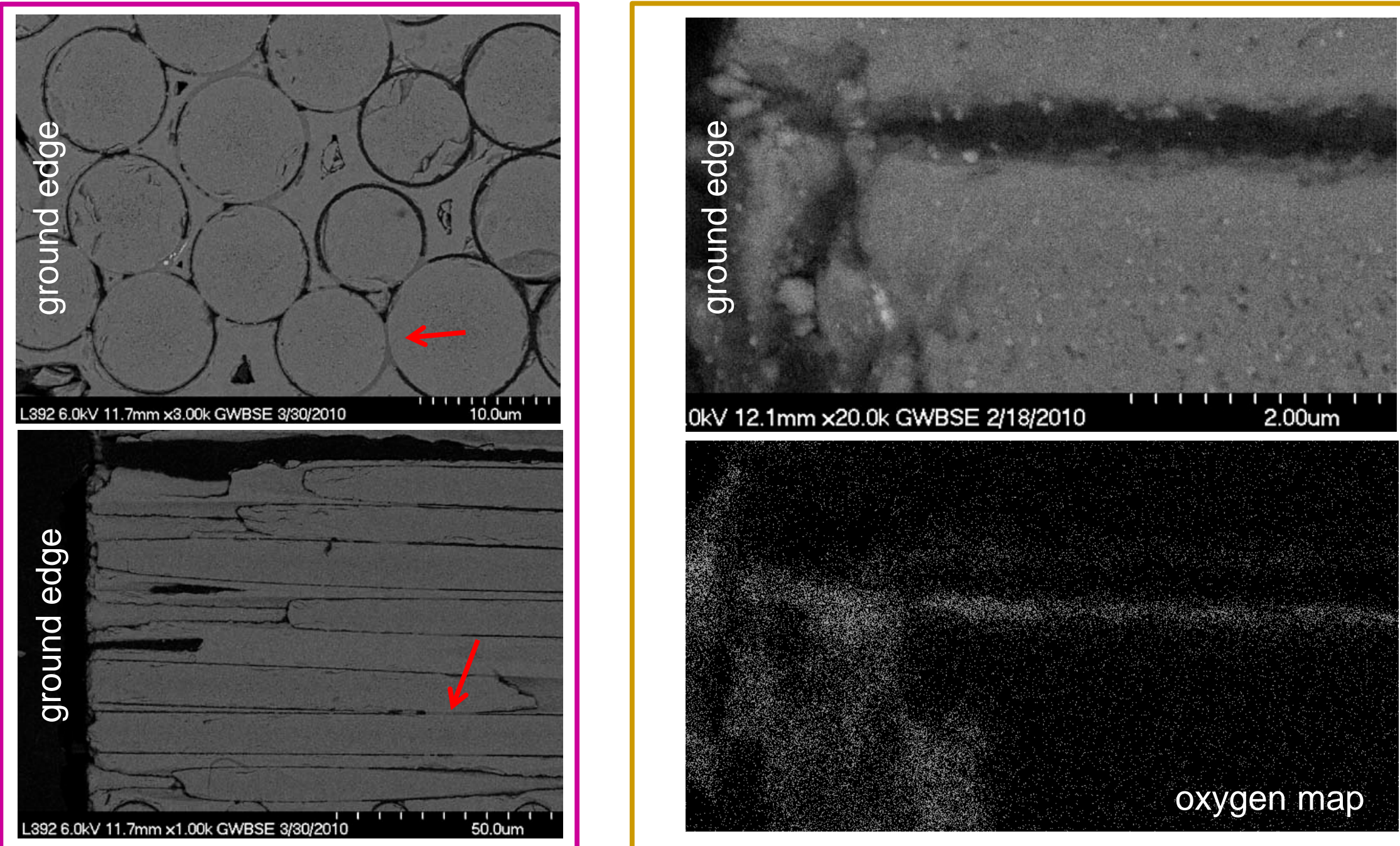

$1149^{\circ} \mathrm{C}, 100 \mathrm{~h}, 1000 \mathrm{ppm} \mathrm{O}_{2}$ : intermittent $\mathrm{SiO}_{2}$ formation

$816^{\circ} \mathrm{C}, 5 \% \mathrm{O}_{2}$ : minimal $\mathrm{SiO}_{2}$ plugging at ground edge, but $\mathrm{SiO}_{2}$ forms on $\mathrm{SiC}$ fibers next to $\mathrm{BN}$ 


\section{Summary of oxygen ingress/loss of BN for $\mathrm{SiC/BN/SiC} \mathrm{composites}$}

\begin{tabular}{|c|c|c|c|c|}
\hline Temp., ${ }^{\circ} \mathrm{C}$ & orientation & $5 \% \mathrm{O}_{2}, 100 \mathrm{~h}$ & $5 \% \mathrm{O}_{2}, 24 \mathrm{~h}$ & $1000 \mathrm{ppm} \mathrm{O}, 100 \mathrm{~h}$ \\
\hline \multirow{2}{*}{1343} & // fibers & $119 \pm 24 \mu m(n=13)$ & $61 \pm 32 \mu m(n=22)$ & $15 \pm 8 \mu \mathrm{m}(\mathrm{n}=16)$ \\
\hline & $\perp$ fibers & 3 fiber diameters & 2 fiber diameters & 1 to 2 fiber diameters \\
\hline \multirow{2}{*}{1149} & // fibers & $2.8 \pm 3.1 \mu \mathrm{m}(\mathrm{n}=16)$ & $3.8 \pm 2.1 \mu \mathrm{m}(\mathrm{n}=35)$ & Intermittent $\mathrm{SiO}_{2}$ \\
\hline & $\perp$ fibers & $<1$ fiber diameter & $<1$ fiber diameter & Intermittent $\mathrm{SiO}_{2}$ \\
\hline \multirow{2}{*}{816} & // fibers & $0.3 \mu \mathrm{m}(\mathrm{n}=2), 5 \mu \mathrm{m}(\mathrm{n}=1)$ & $2 \mu m(n=3)$ & $14 \mu \mathrm{m}(\mathrm{n}=2)$ \\
\hline & $\perp$ fibers & $<1$ fiber diameter & $<1$ fiber diameter & 1 fiber diameter \\
\hline
\end{tabular}

- $\mathrm{Red}=$ depth of $\mathrm{SiO}_{2}$ formed, BN consumed, measured from ground edge

- Blue = depth of BN consumed without $\mathrm{SiO}_{2}$ sealing edge, measured from ground edge

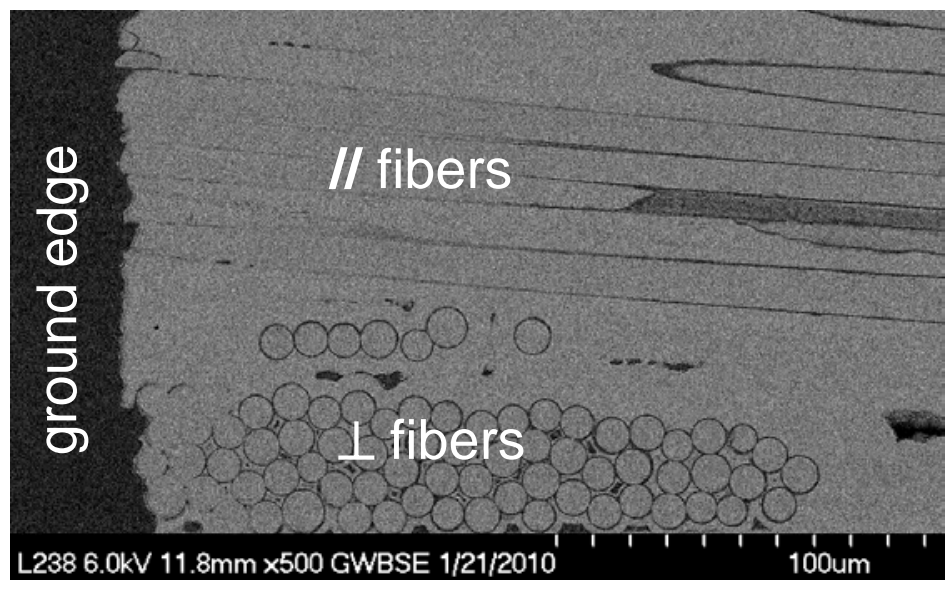




\section{Stability of $\mathrm{BN}$ adjacent to $\mathrm{SiO}_{2}$}

- $\mathrm{BN}$ stability adjacent to $\mathrm{SiO}_{2}$ has been observed previously

- Fibrous Monoliths SiC/BN system, Baskaran \& Halloran, JACerS 77 [5] 1249 (1994).

- Oxidation of BN-Coated SiC Fibers in CMCs, Sheldon et al, JACerS 79 [2] 539 (1996).

- High Temp Oxidation of BN Layers in Composites, Jacobson et al, JACerS 82 [6] 1473 (1999).

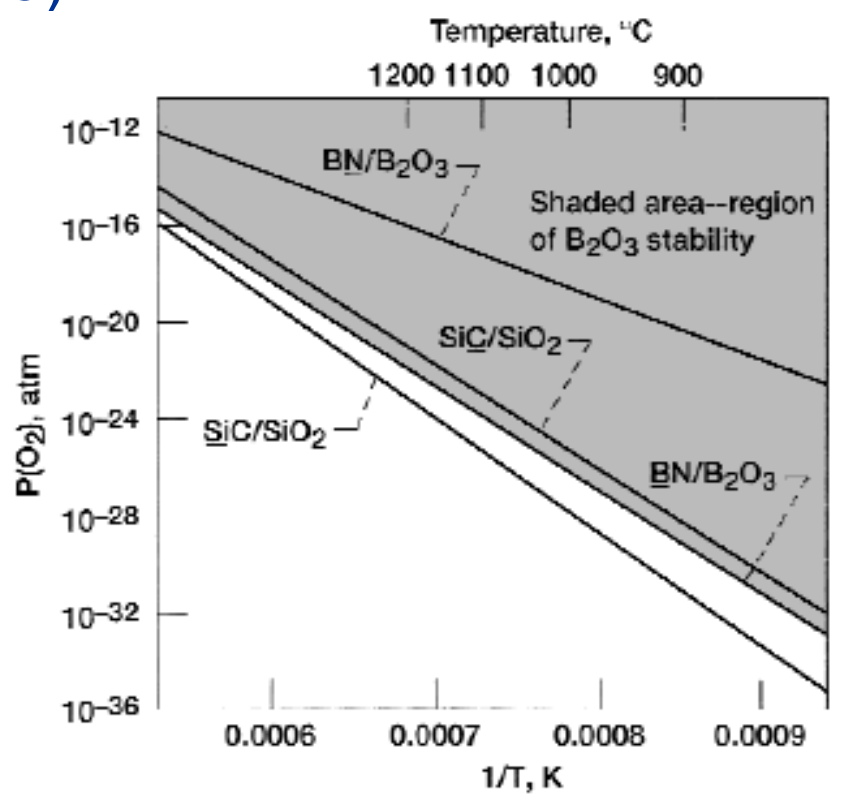




\section{Summary of $\mathrm{SiC} / \mathrm{BN} / \mathrm{SiC}$ oxidation}

- $\mathrm{SiO}_{2}$ formation is observed at all temperatures in 5\% $\mathrm{O}_{2}$ environment. Sealing of exposed BN interphase channels into composite occurs at 1343 and $1149^{\circ} \mathrm{C}$.

- At $1000 \mathrm{ppm} \mathrm{O}_{2}$ condition, some $\mathrm{SiO}_{2}$ formation is observed, but weight loss of composite is observed, indicating loss of $\mathrm{BN}$ without sealing composite. 


\section{Unanswered questions: $\mathrm{SiC} / \mathrm{BN} / \mathrm{SiC}$ composite oxidation}

- Microstructure of composite oxidized at $1343^{\circ} \mathrm{C}$ in $1000 \mathrm{ppm} \mathrm{O}_{2}$ indicates $\mathrm{SiO}_{2}$ sealing of composite, inconsistent with largest observed weight loss.

- Weight loss of composites at $1343^{\circ} \mathrm{C}, 1149^{\circ} \mathrm{C}$ in $1000 \mathrm{ppm} \mathrm{O}_{2}$ is inconsistent with observed weight gain of fibers under same conditions.

- What occurs at $\mathrm{SiO}_{2} / \mathrm{BN}$ interface? How is oxygen transported down interphase region to $\mathrm{SiO}_{2} / \mathrm{BN}$ interface? What oxidation reaction occurs at interface? How are $B$ and $N$ transported from interface?

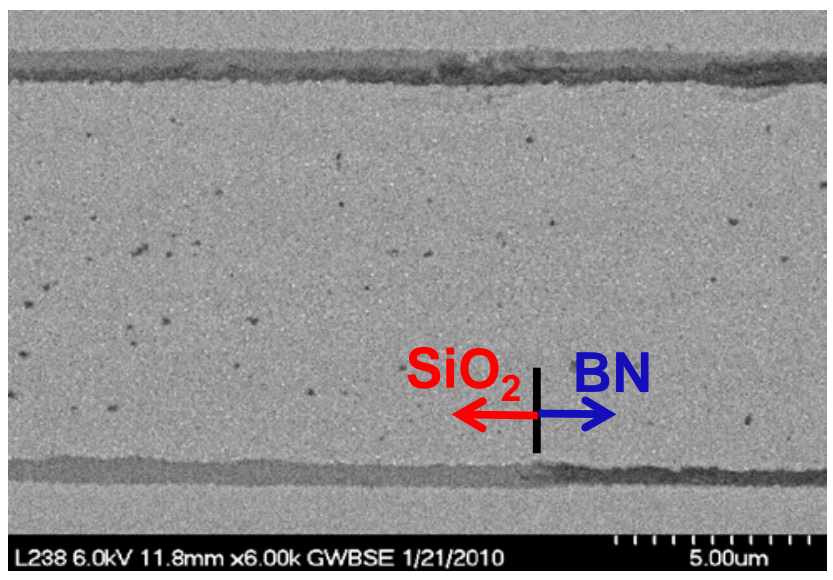




\section{Conclusions}

- Beginning to understand the oxidation behavior of $\mathrm{SiC} / \mathrm{BN} / \mathrm{SiC}$ composites in low oxygen partial pressure environments

- Rapid B-affected oxidation transient of SiC fibers provides mechanism for sealing exposed fibers in composite

- Sealing of exposed fibers in composites occurs for exposures in $5 \% \mathrm{O}_{2}$ environments at 1149 and $1343^{\circ} \mathrm{C}$.

- Inward progression of oxidation $\left(\mathrm{SiO}_{2}\right.$ formation/loss of BN interphase) is $<200 \mu \mathrm{m}$, usually much less: minimal degradation for $100 \mathrm{~h}$ exposure 


\section{Further work}

- Continue to characterize the oxidation of both Sylramic iBN fibers and SiC/iBN/SiC composites, more repeats, higher temperatures $\left(1538^{\circ} \mathrm{C}\right.$, $\left.\left(2800^{\circ} \mathrm{F}\right)\right)$, intermediate oxygen partial pressure $\left(0.5 \% \mathrm{O}_{2}\right)$.

- Characterize oxidation of woven Sylramic iBN fabric with CVI Si-doped BN coating (intermediate processing step)

- Better characterize B-content in thermally grown $\mathrm{SiO}_{2}$. SIMS?

- Role of atomic oxygen in hypersonic environment on $\mathrm{SiC} / \mathrm{BN} / \mathrm{SiC}$ oxidation should be considered, arc-jet exposures? 


\section{Acknowledgment}

This work was funded by the NASA Aeronautics Research Mission Directorate, Fundamental Aeronautics Program on Hypersonics 


\section{Backup charts}




\section{Initial transient weight gain attributed to oxidation of $\mathrm{BN}$, doping of $\mathrm{SiO}_{2}$ scale}

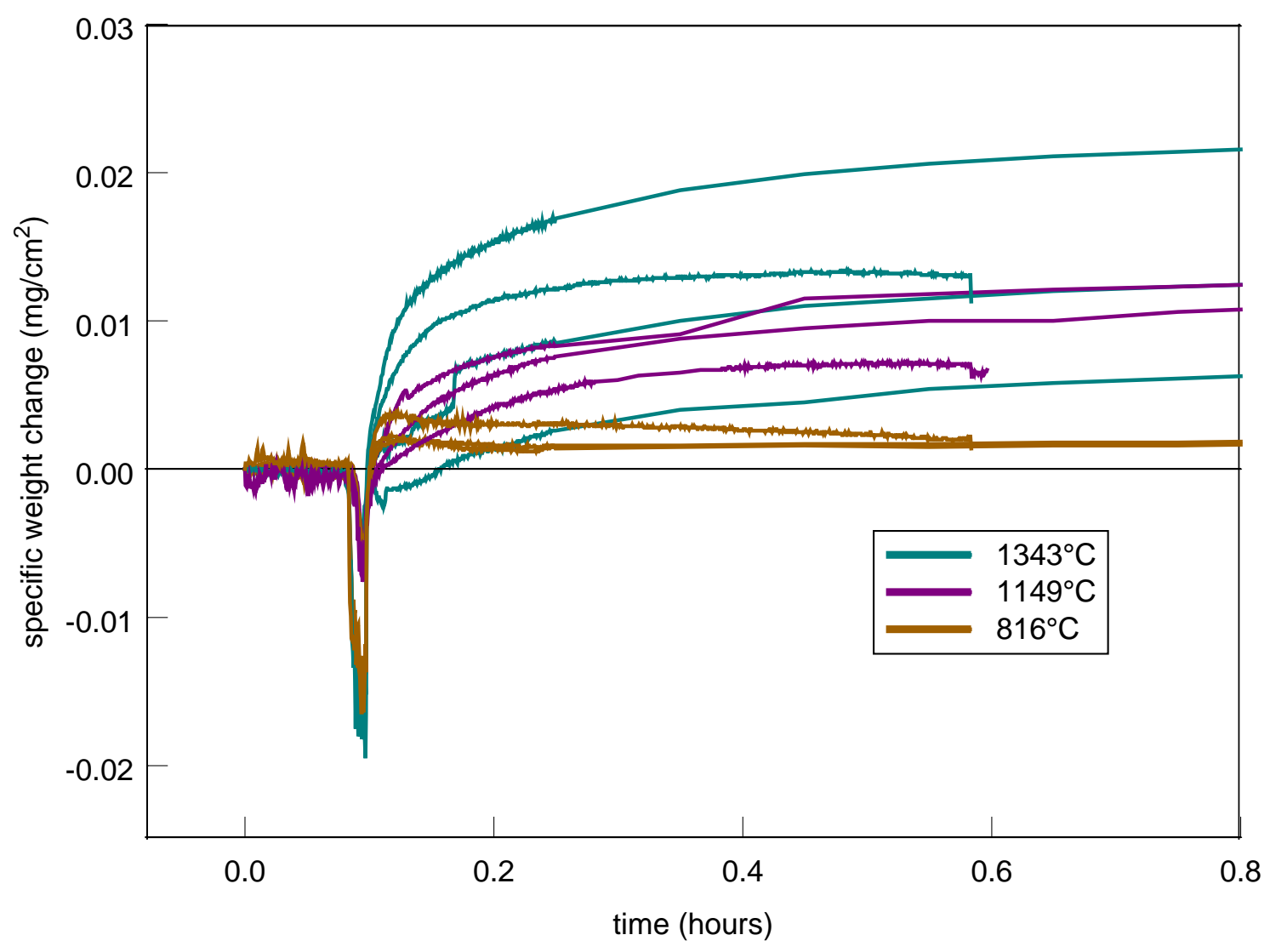

- Initial transient is variable, especially at $1343^{\circ} \mathrm{C}$, possibly due to variable fiber spacing, oxide bridging between fibers, changes of exposed surface area 


\section{Comparison of oxidation rates at various $\mathrm{P}\left(\mathrm{O}_{2}\right)$}
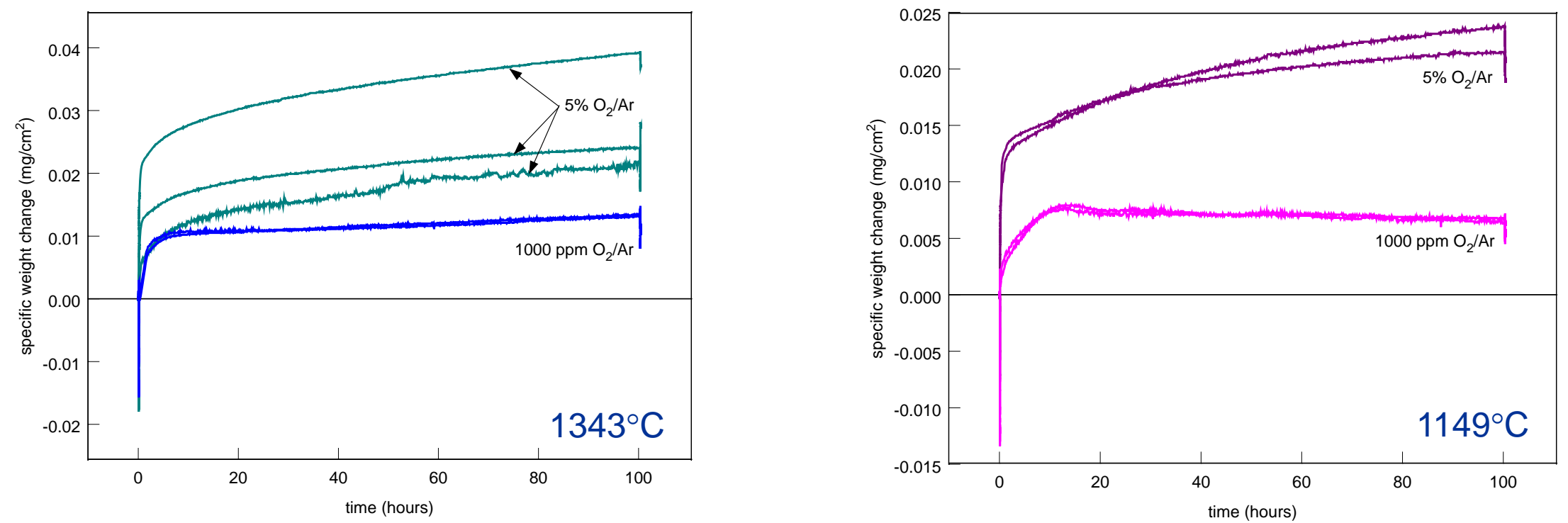

Transient oxidation extended to longer times for 1149 and $1343^{\circ} \mathrm{C}$ exposures.

Oxidation not observed at $816^{\circ} \mathrm{C}$ in $1000 \mathrm{ppm} \mathrm{O}_{2}$.

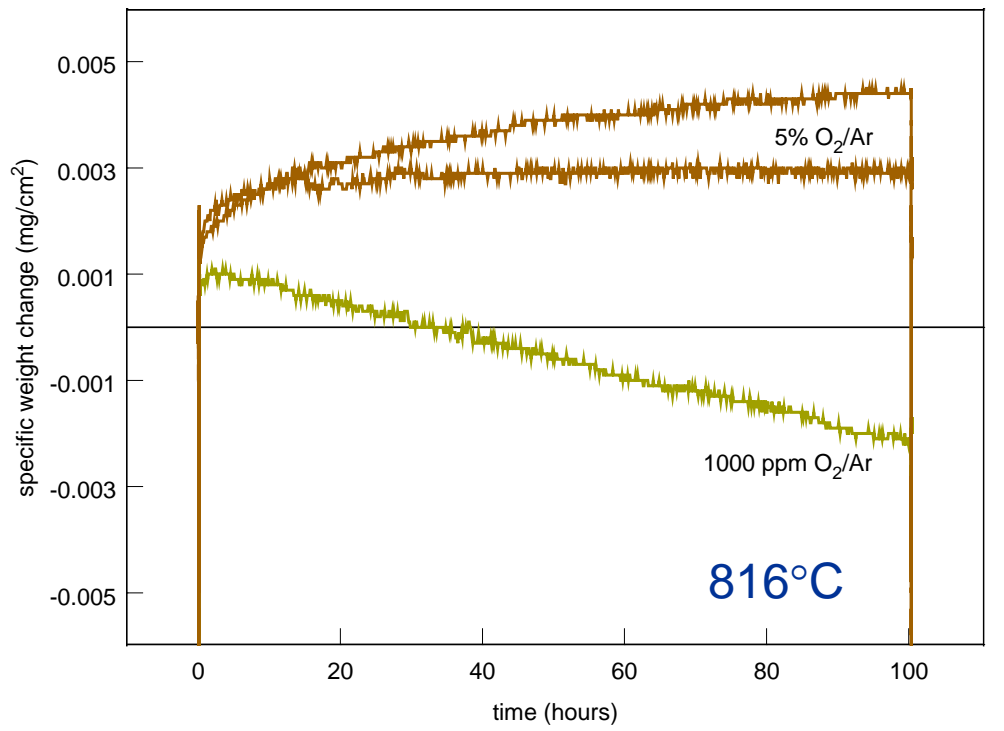

